\title{
Corneal Inflammatory Diseases - Infectious Keratitis in Dogs
}

\author{
H. KECOVÁ ${ }^{1}$, Z. HLINOMAZOVÁ ${ }^{2}$, P. RAUŠER ${ }^{1}$, A. NEČAS ${ }^{1}$
}

${ }^{1}$ Department of Surgery and Orthopaedics, Small Animal Clinic, Faculty of Veterinary Medicine, University of Veterinary and Pharmaceutical Sciences, Brno, Czech Republic

${ }^{2}$ Department of Ophthalmology, Medical Faculty, Masaryk University Brno, Czech Republic

\author{
Received November 11, 2003 \\ Accepted July 29, 2004
}

\section{Abstract}

Kecová H., Z. Hlinomazová, P. Raušer, A. Nečas: Corneal Inflammatory DiseasesInfectious Keratitis in Dogs. Acta Vet. Brno 2004, 73: 359-363.

This article compares different aspects of corneal infection in human versus veterinary medicine. It emphasizes different aetiology of development of corneal infection and distinct number of pathogens employed (monoinfections in people versus often mixed infections in dogs). Contrary to humans, thanks to common multifactorial aetiology of infections in animals, it is not easy to predict causal organism on the basis of clinical signs. Diagnostics thus relies mainly on cytology and microbial culture. Since rapidly developing and eye-threating infections in dogs exist, the techniques such as polymerase chain reaction may be the future help in prompt assesment of dangerous ocular pathogens in the cases of profound corneal infections.

\section{Corneal infection, dog, aetiology, diagnostics}

Corneal inflammation is one of the most common ocular diseases in both humans and animals and can lead to blindness or even cause lost of the eye itself (Whitley and Gilger 1999; Ollivier 2003). In humans, keratitis is classified into infectious and non-infectious, while in veterinary medicine the tradition is to classify keratitis rather into ulcerative and non-ulcerative (Whitley and Gilger 1999). Non-ulcerative keratitis in dogs is usually caused by mechanical irritation (pigmentary keratitis) or by immune-mediated process (pannus). However, non-ulcerative infectious keratitis also exists (corneal abscess, mycotic, viral keratitis). Ulcerative keratitis can be of non-infectious (recurrent erosions, traumatically induced superficial ulceration) or infectious (bacterial, viral, mycotic) origin. Even in the cases of originally non-infectious ulceration, after disruption in the epithelium secondary infection often occurs (B istner 1981; Whitley 2000).

In recent years, keratitis in people seems to be complicated by several factors such as unhealthy style of living and eating, presence of antibiotics in environment (food chain), increasing occurrence of systemic diseases (diabetes mellitus, immunodeficiences) or increasing use of local and/or systemic drugs, often without doctor's prescription. The consequences are dramatical changes in clinical findings and courses of various diseases. Formerly acute diseases with clinical signs typical for aetiologic agents are now presenting as chronic processes. Aetiologic agents themselves also change, influenced by the environment. Considering the fact that dogs live in close connection with people (same environment, often eating same food) and that systemic diseases in them are also more common, it is probable that similar trends will occur in our pets as well. Regardless of all mentioned complications, peoplepatients, as well as people-animal owners, want rapid and adequate treatment, that is absolutely effective and pain-free. These facts advocate the necessity of rapid diagnosis of aetiology of keratitis to accelerate iniciation of causal treatment.

Address for correspondence:

MVDr. Helga Kecová

Department of Surgery and Orthopaedics

University of Veterinary and Pharmaceutical Sciences

Palackého 1-3

61242 Brno, Czech Republic

Phone: +420606 321211

E-mail: hkecov@hotmail.com

http///www vfu.cz/acta-vet/actavet.htm 
Eye protection mechanisms

The dog eye has to face many potentially pathogenic agents and that is why it is well protected by several mechanisms from injury and/or infection. The lids and the third eyelid serve as a mechanical barrier against microbial invasion as well as to mechanical damage which is a leading cause of corneal infection in dogs. Another protective mechanism is a blinking reflex, which enables continuous washing of cornea with a tear film. Besides flushing of impurities and debris from ocular surface, tear film contains several immune-active substances (lysozyme, $\beta$ - lysin, lactoferrin, immunoglobulins - especially actively secreted IgA) which represent non-specific protection of the eye. The most important barrier against invasion of pathogens is corneal epithelium - regular sloughing of epithelial cells (turnover 5-7 days) precludes adherence of bacteria, tight junctions of cells and basement membrane prevent deep infiltration of bacteria. Also the normal (resident) ocular flora interferes with microorganism colonisation (Gerding and Kakoma 1990; Ollivier 2003). The main factors remarkably contributing to development of keratitis are microtraumas; other causes are tear film disturbances, disorders of the immune system (immunodeficiencies, autoimmune diseases), and corneal surgical interventions (Bistner 1981; Moore and Nasisse 1999).

Characterisation of infectious agents

Bacteria and fungi cause various ocular diseases in dogs, including keratitis. In this species, bacteria are the most important pathogens. Viral corneal infections are infrequent, mycoplasmal and chlamydial corneal infections in dogs are not mentioned at all.

$\mathrm{B}$ acteria are procaryotic organisms enclosed in a cell wall. Their DNA is organised into circular chromosome and additional smaller DNA structures called plasmids, responsible for resistance to drugs. According to temperature demands, bacteria are classified into 3 groups: psychrophilic $\left(0-20^{\circ} \mathrm{C}\right)$, mesophilic $\left(20-40^{\circ} \mathrm{C}\right)$ and termophilic $\left(40-90^{\circ} \mathrm{C}\right)$. Most bacteria are mesophilic, but some of them can grow even at lower temperatures (Staphylococcus, Streptococcus).

Fungi are eucaryotic organisms enclosed in a cell wall. They grow from spores; optimal temperature for growth of fungi is $20-40{ }^{\circ} \mathrm{C}$ with $40-50 \%$ humidity.

Classification of microorganisms

Microbial flora of the cornea and conjunctiva can be divided into resident (commensal) and transient (opportunistic pathogens) organisms. Resident flora consists of non-invasive organisms that are considered to be normal inhabitants of canine conjunctiva and cornea. They are usually isolated from bacteriologic samples of ocular surface in large numbers. This flora inhibits growth of pathogens by nutritional competition, occupying space and also by secretion of active substances that inhibit transient flora (Gaskin 1980; Gerding and Kak o ma 1990). Thus, resident flora is an important part of eye protection against infection. When resident flora is inhibited by disease or long-term application of antibiotics and/or corticosteroids, opportunistic pathogens can expand and disease develops. Transient flora is represented by microorganisms that are from bacteriologic samples isolated infrequently, and if so, in much smaller amounts than resident flora.

Resident flora varies between species and even within one species it can differ according to environment, climate, season, as well as with different sampling techniques (Gerding and Kakoma 1990). However, in dogs it consists mainly of Gram+ microorganisms. With ocular disease, there is a tendency for change in distribution of bacterial species, with increasing proportion of G- bacteria. According to some studies (Gaskin 1980) bacteria were isolated in 68-78\% of examined healthy dogs' eyes. The most commonly isolated bacteria with external ocular disease were staphylococci including potentially pathogenic $S$. aureus. Other resident bacteria were isolated much less frequently (Streptococcus sp., Enterococcus sp. and others) (Gerding and Kakoma 1990). 
Transient flora is represented by organisms of low pathogenicity (Staphylococcus epidermidis, Bacillus sp., Corynebacterium sp., E. coli, Enterobacter sp.); the infection usually develops in cases of immunodeficiences or as a co-infection.

Pathogenic and opportunistic pathogenic flora (Moore and Nasisse 1999)

$\mathrm{G}+$ bacteria. Staphylococcus sp. is ubiquitous on skin and mucous membranes; it can cause suppurative infections of ocular and periocular tissues. The most common isolates from ocular infections are coagulase-positive $S$. aureus and $S$. intermedius and coagulasenegative $S$. epidermidis. Staphylococci are known to produce enzymes such as coagulase, hemolysin, collagenase, hyaluronidase, protease and other, they also produce dermonecrotoxin. S. intermedius can develop multiple antibiotic resistance. Streptococcus sp. is ubiquitous, suppurative bacteria, normally present on mucous membranes. They also produce exotoxins and are common isolates from keratitis in domestic animals, the most pathogenic being $\beta$-hemolytic streptococci. Corynebacterium sp. can be part of normal flora of skin and mucous membranes. They are pyogenic and have been isolated from cases of corneal ulceration, mostly as mixed infections. Bacillus sp. are large spore-forming rods, aerobic or facultatively anaerobic. Bacilli were cultivated from infected corneas in animals, but mostly as a part of mixed infection, thus their pathogenicity in these diseases is controversial.

G- bacteria. The most important G- bacteria is Pseudomonas sp. It is a saprophyte, widely distributed in environment, also commonly found on skin and mucous membranes. The most frequent in ocular disease and also most pathogenic individual is $P$. aeruginosa. It is isolated from cases of profound keratitis and can cause rapid progressive destruction of the cornea (it produces proteases, hemolysin and endo- and exotoxins). Cornea is susceptible to pathogenic effects of Pseudomonas especially when the epithelium is damaged. $P$. aeruginosa keratitis in dogs is quite serious and relatively common disease. Other G- bacteria isolated from corneal diseases in animals (including dogs) are Neisseria sp. and Enterobacteria (E. coli, Serratia sp., Proteus sp., Citrobacter and others). They are of low pathogenic potential and are cultivated from mixed infections, most commonly in cases of epithelial defects and/or immunodeficiencies.

Anaerobic bacteria. These bacteria cause mainly deep tissue infections (orbital cellulitis, abscess). From infected corneas, Clostridium was sporadically cultivated as part of mixed infection.

Fungal pathogens. Fungi cause either superficial diseases (keratomycoses), or deep infections (systemic, including ocular manifestation). In dog, systemic fungal infections are far more common than keratomycoses (Andrew 2003). Keratomycoses are considered rare diseases in dogs (Gerding et al. 1988; Marlar et al. 1994). The causative organisms mostly include Aspergillus and Candida sp. (Qualls et al. 1985; Gerding and Kakoma 1990; Mas s a et al. 1999).

Viruses. Viruses seldom cause keratitis in dogs. Canine Herpesvirus can cause systemic infections in newborn puppies; these infections can be accompanied by keratitis, uveitis and retinal necrosis.

Clinical diagnostics

Diagnostics of infectious keratitis relies on clinical examination, cytology and microbiologic examination (Mas s a et al. 1999; S latter 2001; Ollivier 2003). The best way to make a definitive diagnosis of infectious ulcerative keratitis is to use both cytology and microbiology together, especially in animals receiving antibiotics from referring veterinarian (Mas s a et al. 1999). Clinical signs of keratitis of different aetiology are ocular hyperemia ("red eye"), pain, photophobia, blepharospasm, variable degree of corneal infiltration and vascularisation, often accompanied by corneal ulceration. This can affect 
any of corneal layers, or all of them. It can be also accompanied by inflammation in the anterior chamber. In cases of bacterial keratitis, corneal ulceration and purulent or mucopurulent discharge is common (Whitley 2000).

In people, corneal infection tends to be monoaetiologic and many of infectious agents have typical clinical presentation. Some of the clinical signs are pathognomic.

Contrary to this, in dogs primary infectious keratitis is uncommon. Corneal infection is usually enhanced by disruption of the epithelium, which enables invasion of bacteria (Whitley 2000; Ollivier 2003). Other causes are immunodeficiencies or long-term application of antibiotics and/or corticosteroids. When present, corneal infection in animals is often multifactorial (Moore and Nasisse 1999) and in such cases clinical presentation is not pathognomic. Clinical appearence of keratitis highly depends on type of infectious agents, its virulence and duration of the infection.

In differential diagnosis of infectious keratitis we must still keep in mind the whole range of non-infectious keratitis.

Laboratory diagnostics

Bacterial/fungal culture. When taking samples for culture from the ocular surface, one must be aware that the number of collected organisms is limited. Thus, the way of collection, storage and transport of samples is often critical. When topical anesthetics or dyes are instilled prior the collection of samples, preservatives from the drops will inhibit growth of microorganisms (Ward 1999). Contamination of the sample from eyelids will lead to overgrowth of commensal flora of eyelids (most commonly staphylococci and streptococci). Also incorrect transport medium or prolonged time before inoculation onto culture medium will lead to failure of diagnosis.

Suitable collecting devices are calcium alginate swabs moistened with trypticase soy broth, dacron/rayon swabs soaked in thioglycolate broth, sterile Kimura spatula or Bard Parker blade (corneal scraping with direct spread on culture media, especially when expecting fungal organisms) and, to a lesser degree also sterile cotton swabs. Most commonly used culture media are blood or chocolate agar for bacteria and Sabourad's dextrose medium for fungi (Mas sa et al. 1999).

Cytology. Cytobrushes, Kimura spatula or Bard Parker blade are used to scrape the cornea and the sample is placed onto a slide and let dry. Gram, Giemsa or the quick stains (Diff Quick) are used most commonly (Gerding et al. 1988; Slatter 1990; Ollivier 2003). In most cases cytology is not diagnostic for specific bacteria (lot of bacteria look similar on microscopic examination), thus cultivation still remains necessary in diagnosing aetiologic agents. In many organisms testing of susceptibility to antibiotics is advisable due to posibility of drug resistance.

Other. As viral diagnostics is far more complicated compared to bacterial or fungal, DNA diagnostics is becoming more popular in viral infections. Polymerase chain reaction (PCR) is an enzymatic amplification method, where a section of DNA typical of specific organism is isolated and detected. This method enables not only rapid, but also precise diagnostics of infectious keratitis; it is most commonly used in herpes and adenoviral infections in people. This method is becoming more popular even with fungal infections.

In conclusion, gradually changing clinical presentation of individual corneal infections or their multifactorial aetiology complicate clinical diagnostics. Regarding the fact that with corneal inflammation opacification to different extent develops and thus cornea is loosing its transparency, prompt diagnosis and causal therapy is vital for preserving good sight. DNA diagnostics in some cases of ocular infections can markedly shorten the time necessary for detection of pathogen and thus accelerate iniciation of causal treatment. This can be particularly important in severe cases of corneal infections accompanied by rapid melting of the corneal stroma. 


\section{Zánětlivá onemocnění rohovky - infekční keratitis u psů}

Článek poukazuje na různé aspekty infekční keratitidy v humánní a veterinární medicíně. Vyzdvihuje rozdílnost jejich etiologie a různé množství uplatňujících se organismů (monoinfekce u lidí versus často smíšené infekce u psů). Na rozdíl od lidí, u psů se na infekcích rohovky běžně podílí více organismů a proto není snadné určit původce podle typických klinických př́iznaků. Diagnostika je tak závislá na cytologii a mikrobiální kultivaci. Vzhledem k tomu, že se i u psů vyskytují progresivní a oko ohrožující infekce, techniky jako PCR mohou být $\mathrm{v}$ budoucnu dủležité pro rychlé stanovení původců $\mathrm{v}$ případech těžkých rohovkových infekcí.

\section{References}

ANDREW SE 2003: Corneal fungal disease in small animals. Clin Tech Small Anim Pract 18: 186-192 BISTNER S 1981: Clinical diagnosis and treatment of infectious keratitis. Compend Contin Educ Pract Vet 3: 1056-1066

GASKIN JM 1980: Microbiology of the canine and feline eye. Vet Clin North Am Small Anim Pract 10: $303-316$ GERDING PA, McLAUGHLIN SA, TROOP MW 1988: Cytology of normal and inflammed conjunctivas in dogs and cats. J Am Vet Med Assoc 172: 66-68

GERDING PA, McLAUGHLIN SA, TROOP MW 1988: Pathogenic bacteria and fungi associated with external ocular diseases in dogs: 131 cases (1981-1986). J Am Vet Med Assoc 193: 242-244

GERDING PA, KAKOMA I 1990: Microbiology of the canine and feline eye. Vet Clin North Am Small Anim Pract 20: 615-625

MARLAR AB, MILLER PE, CANTON DD, SCAGLIOTTI R, MURPHY CJ 1994: Canine keratomycosis: a report of eight cases and literature review. J Am Anim Hosp Assoc 30: 331-340

MASSA KL, MURPHY CJ, HARTMANN FA, MILLER PE, KORSOWER CS, YOUNG KM 1999: Usefulness of aerobic microbial culture and cytologic evaluation of corneal specimens in the diagnosis of infectious Ulcerative keratitis in animals. J Am Vet Med Assoc 215: 1671-1674

MOORE CP, NASISSE MP 1999: Clinical microbiology; in: Gelatt KN: Veterinary Ophthalmology (Ed 3), Philadelphia, PA, Lippincott Williams \& Wilkins, pp. 259-290

OLLIVIER FJ 2003: Bacterial corneal diseases in dogs and cats. Clin Tech Small Anim Pract 18: 193-198 QUALLS CW Jr., CHANDLER FW, KAPLAN W, BREITSCHWERDT EB, CHO DY 1985: Mycotic keratitis in a dog: concurent Aspergillus sp. and Curvularia sp. J Am Vet Med Assoc 186: 975-976

SLATTER D 2001: Fundamentals of Veterinary Ophthalmology (Ed 3). Philadelphia, PA, Saunders, pp. 293-295 WARD DA 1999: Clinical pharmacology and therapeutics, part III.; in: Gelatt KN: Veterinary Ophthalmology (Ed 3), Philadelphia, PA, Lippincott Williams \& Wilkins, pp. 336-354

WHITLEY RD, GILGER BC 1999: Diseases of cornea and sclera; in: Gelatt KN: Veterinary Ophthalmology (Ed 3), Philadelphia, PA, Lippincott Williams \& Wilkins, pp. 635-673 
Plate IV

Kecová H. et al.: Corneal Inflammatory ... pp. 359-363

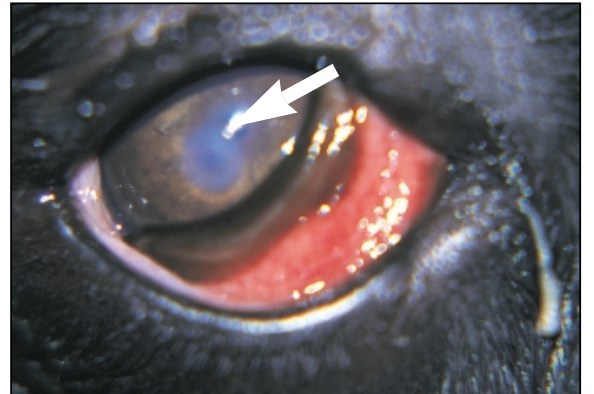

Fig. 1. Rottweiler, 3 yrs, female, corneal superficial wound (arrow) due do accidental injury (wire)

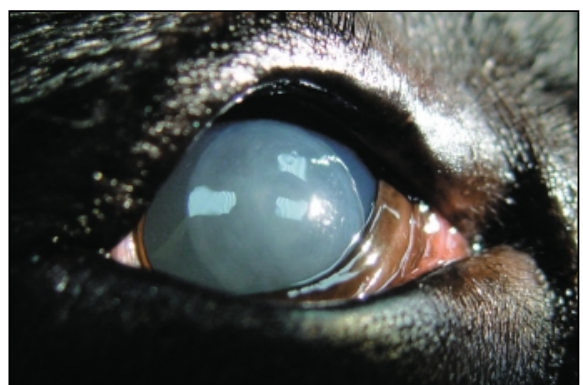

Fig. 3. Same patient after institution of causal therapy ( 1 month post injury), corneal ulcer healed with intense corneal opacification

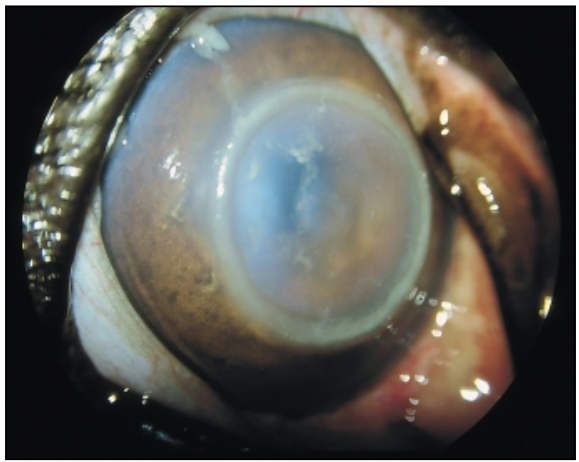

Fig. 2. Same patient, 10 hours after injury and iniciation of therapy (ineffective intibiotics)

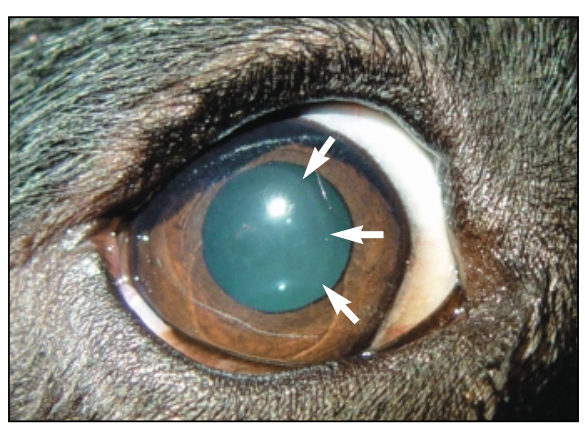

Fig. 4. Same patient 2 months post injury, clear cornea, only subtle haze (arrows) visible upon close exam 